\title{
Impact of Project Teamwork on Project Success in Pakistan
}

\author{
Syed Muhammad Javed Iqbal * Muhammad Shahid Nawaz $^{\dagger}$ Salman Bahoo ${ }^{\ddagger}$ \\ S.M. Labib Abdul Ba'ith Shah Bukhari §
}

\begin{abstract}
The contribution of project teamwork is based on project members toward project success has remained unattended in prior literature. This paper highlights the importance of project teamwork for the project success and argues that leader alone cannot successfully complete a project. This study is based upon Higher Education Commission (HEC)'s projects in Pakistan and data has been collected from project leaders regarding performance and contribution of project teamwork toward project success. The study hypothesized the positive and direct relationship between the project teamwork and project success. For the purpose of verification of this relationship the project managers were requested through e-mail to complete questionnaires. Further, this relationship is verified theoretically and empirically by applying Partial Least Square-Structural Equation Modeling (PLS-SEM). It is concluded on the basis of results that project team work has positive and direct relationship with project success. The study findings will be helpful for policy makers and project team leaders to understand the importance and contribution of project teamwork toward achieving project success especially in developing countries.
\end{abstract}

Keywords: Project management, project success, project teamwork project team members, and structural equation modeling.

\section{Introduction}

Project leaders can play a significant role to influence the project success positively with and through their team members that are called project teamwork but surprisingly prior literature shows the myopic view and ignored the role of project team members toward project success. According to Sheard and Kakabadse (2002) a project leader should also consider importance of project teamwork for success of any project. However, few researchers have investigated this relationship between project success and project teamwork. This study is an endeavor to consider the success of Higher Education Commission (HEC) through the project teamwork in Pakistan. Meredith and Mantel Jr (2011) argued that inappropriate teams can lead a project towards failure. Therefore, the importance and impact of project teams on project success or failure cannot be ignored. Verburg, BoschSijtsema, and Vartiainen (2013) argued that good project teamwork is vital for project

\footnotetext{
*Department of Commerce Islamia University of Bahawalpur. E-mail: javed.iqbal@iub.edu.pk

${ }^{\dagger}$ Department of Management Sciences SZABIST Islamabad. E-mail: shahidnawaz702@gmail.com

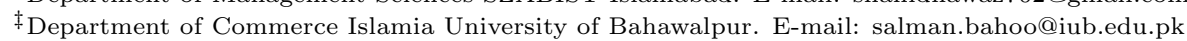

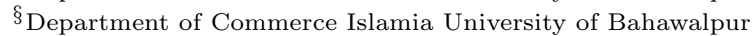


success and project leader will be effective only in case of proper, operative and competent project team members (Thamhain, 2004). The term project teamwork means the discussion about the team members that are working in a project under some leadership. The good project teamwork is based on the "teamwork processes" that are required components for an effective team. Such as, Dionne, Yammarino, Atwater, and Spangler (2004) recommended the team communication and cohesion as component of teamwork processes and asserted that there are many teamwork factors that can be considered in teamwork processes. According to Yang, Huang, and Wu (2011) the project teamwork processes is based on three-dimensional construct like project team communication, cohesiveness and collaboration among team members.

In this study, we are considering the four dimensions for project teamwork processes like project team; communication, cohesiveness, collaboration and technical skills. The finding of this study is a contribution in existing literature and knowledge by considering existing three and adding new dimension of technical skills for team members. The argument behind the consideration of technical skill is that in project management the technical skills are essential for team members to identify and solve problems during working of a project (Slevin \& Pinto, 1986; J. K. Pinto \& Mantel, 1990).

We mainly focused on the project success as central variable to investigate the factors that increase chances of project success. Because project failure rate has been recorded more than success in all over the world and Pakistan also has no exception. The one of major reasons behind the failure of each project is uniqueness, as the literature is lacking pre-sets of standards to determine the universal project success (Muller \& Jugdev, 2012). It is pertinent to mention that project failures ultimately affect national economies (Zwikael \& Unger-Aviram, 2010). Consequently, the researchers and academicians are continuously striving to find those factors that can enhance chances of project success. Striving to find those factors that can enhance chances of project success (Alderman \& Ivory, 2011).

Similarly, Afzalur Rahim, Antonioni, and Psenicka (2001) explained in the light of Asian Development Bank's report that average success rate of different projects in Pakistan is remained $48 \%$ and especially educational projects is only $30 \%$ (Daily Times, 2011) within a decade of 2002-2012. Higher Education Commission of Pakistan is sole institution that dealing with higher education projects in Pakistan and playing main role (Ghori, 2009). Further, it is claimed that despite the Higher Education Commission of Pakistan providing facilitation towards the higher education projects the success rate is very low and this issue failed to get attention of researchers (Iqbal, 2011).

The drive of this study is to transform the attention of policy makers and practitioners toward project success through the project teamwork in Pakistan. As being the developing country, it is need of the time to understand the role and importance of successful projects at organizational and national level.

\section{Literature Review}

Project teamwork has been considered as a causal variable to improve the project success and it is based on teamwork processes that are required components for an effective team. 
Such as Dionne et al. (2004) recommended that team communication and cohesion as component of teamwork processes and asserted that there are many teamwork factors that can be considered in teamwork processes. Similarly, Yang, Wu, and Huang (2013) investigated the project team's communication, cohesiveness and collaboration as project teamwork component.

Likewise, there is no exact definition of project success in the extant literature. It is considered as a multidimensional construct and has different meanings to different persons. According to J. Pinto (1996) the project success has long been measured against traditional factors for instance, the project was completed within specified time, cost constraint and performs as expected, generally known as triple constraint and the iron triangle (Atkinson, 1999; J. K. Pinto \& Mantel, 1990).

During the last few years, J. Pinto (1996) reassessed this traditional model of project success and argued that this old triple constraint needs to be replaced by a new model by introducing a fourth constraint of project success, i.e. satisfaction of client because, ultimately a project is considered successful if the clients are satisfied. He termed these four criteria of perceived project success as "quadruple" constraint model. The current study not only addresses the quadruple constraint model of J. Pinto (1996), but also considers the impact of project success on organizational success. Finally, the study selected this particular combination as, J. K. Pinto and Mantel (1990) argued that these factors are general enough, which can be applied across a variety of organizations and project types.

Prior literature is lacking a comprehensive study tapping the impact of project teamwork on the success of project (Yang et al., 2013). Current research has ambitions to investigate the relationships amid project teamwork and project success in projects of higher education in Pakistan. Hence, the study endeavored to find the answers of the given research questions.

- What is the impact of project teamwork on project success factors?

- Which of project teamwork dimension has most significant impact on project success factors?

\section{Relationship between Project Teamwork and Project Success}

The researchers posed that project teamwork may have a positive and significant contribution towards success of any project. According to M. Afzalur Rahim (2001) that performance of the team is positively related to the outcomes of projects. However, there is no empirical study showing the association between project teamwork and project success in any particular industry (Yang et al., 2013). Similarly, Unger-Aviram, Zwikael, and Restubog (2013) indicated that project efficiency can be measured in terms of project team performance which refers to the extent that project team members have completed the project as predefined cost and schedule. They claimed that higher the team efficiency will result in lower the deviation in estimated time and cost of project. As the project teamwork, has been discussed through four layers of project efforts i.e. project team communication, collaboration, cohesiveness and their technical skill. Following literature has been arranged to determine a relationship between project teamwork individual dimensions 
with project success. The researchers have described that better the team performance, higher the project success rates.

Solomon et al. (2001) specified that communication plays an important role in team performance. Similarly, various researchers have concluded that team communication remained one of the effective tool to enhance the performance of the team (Kotlarsky \& Oshri, 2005; Thamhain, 2004). In addition, team cohesiveness is also essential factor for better project performance (Levine \& Moreland, 1990; McGrath, 1964). They concluded that stronger the team cohesiveness will better the performance of the project. Team cohesiveness can also be judged from desire of team members that either they agree to remain in the team or not (Wang, Chou, \& Jiang, 2005). Moreover, Yang et al. (2013) argued that team cohesiveness is one of the important factors for project success.

Team collaboration is another important factor in teamwork which means working together in a united way (Thamhain, 2004). Collaboration between team members strengthens the relationship at work (Nelson \& Cooprider, 1996). Additionally, Gladstein (1984) asserted that team collaboration is a significant factor in performance of a team. Similarly, (Kotlarsky \& Oshri, 2005) specified that effective team performance may be the result of successful collaboration among team members.

Moreover, Shenhar and Dvir (1996) argued that team members' technical qualification is also highly demanded factor for the project success. Likewise, Zwikael and UngerAviram (2010) asserted that skillful project teams are necessary for the accomplishment of the desired success. Similarly, Dong, Chuah, and Zhai (2004) argued that technical skill of project team is important factor for project success. Therefore, those project teams who possess technical knowledge and skills can be found effective in timely solving the problem, accomplishing the project in time and as per desired quality (Clark \& Fujimoto, 1991; Atuahene-Gima, 2003; Scott-Young \& Samson, 2004). Finally, Baker, Murphy, and Fisher (2008) argued that a project success is incomplete until and unless a project meets the technical specifications of the project. Therefore, a project team with appropriate interpersonal skills along with technical skills can be an essential tool for the success of a project. Similarly, Yang et al. (2013) concluded that project teamwork is positively correlated with project success. They asserted that further empirical studies should be carried out in different industries, to know the potential effect of the above stated relationships, as previous researchers have mostly discussed project related studies in projects other than higher education (Giritli \& Civan, 2008; Ozorovskaja, Voordijk, \& Wilderom, 2007; Sunindijo, Hadikusumo, \& Ogunlana, 2007; Yang et al., 2013). Therefore, the study contributes in existing literature, by addressing the impact of project teamwork on project success in higher education sector of Pakistan. The researchers found in literature that every project keeps its own unique characteristics; therefore, a best combination of project team could be utilized to get the desired project success. On the basis of quoted discussion, researchers hypothesized as follows:

$H_{1}$ : The relationship between project team communication and project success is positive and significant.

$H_{2}$ : The relationship between project team cohesiveness and project success is positive and significant. 
$H_{3}$ : The relationship between project team collaboration and project success is positive and significant.

$H_{4}$ : The relationship between project technical skill and project success is positive and significant.

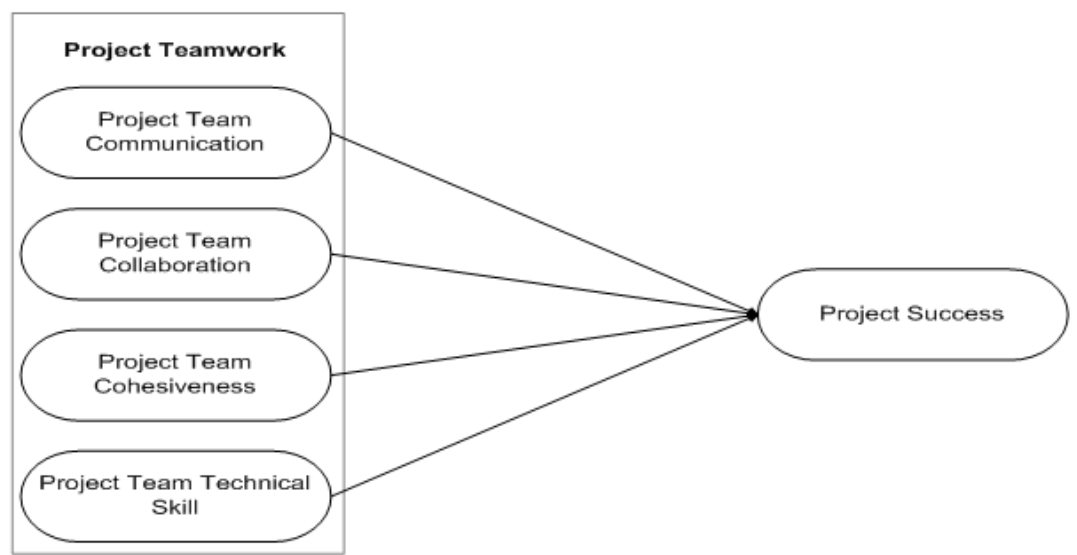

\section{Methodology}

The current study is following the quantitative approach and employing survey research method. There are some favourable factors which are considered significant for the selection of survey method such as, geographic flexibility, cost and for quick and efficient response (Sekaran \& Bougie, 2010). The utilized study instrument contained two parts, measuring the primary project variables, i.e. (project teamwork and project success, respectively). Project teamwork individual dimensions were adopted from the different well known authors representing in the following discussion. The project team communication and collaboration were taken from (Tjosvold, 1988; Campion, Medsker, \& Higgs, 1993). While the project teams cohesiveness was extracted from (Wang et al., 2005). The project team technical skill was and project success factors were measured through the inventory of J. K. Pinto and Mantel (1990). The researchers distributed a total of 198 questionnaires to project managers for data collection regarding their team members contribution toward project success through courier service. The sample size was determined following the guidelines of Krejcie and Morgan (1970). The sample was selected applying the systematic random technique. Among the issued questionnaire, a total of 129 respondents gave their feedback. Out of them 125 responses were found complete in all aspect, resulting $63 \%$ response rate. According to the study settings, the researchers encountered the PLS-SEM technique best for the data analyses (Ringle, Sarstedt, \& Straub, 2012). The applicability and usefulness of PLS-SEM is ever increasing multivariate technique in social sciences (Hair, Sarstedt, Pieper, \& Ringle, 2012; Hair, Ringle, \& Sarstedt, 2013). This technique is based on a series of ordinary least squares regressions and particularly beneficial in case 
of small sample sizes (Chin, 2010; Lu, Kwan, Thomas, \& Cedzynski, 2011). Moreover, PLS-SEM has higher levels of statistical power than covariance-based methods (Reinartz, Haenlein, \& Henseler, 2009). Following sections contain the discussion and findings of the data analyzed.

\section{Discussions and Findings}

In this section, the researchers have tested the theoretical models on two main aspects. The first is termed as measurement model and later is represented as structural model.

\section{Testing the Measurement Model}

For reflective constructs in a model, before testing the structural model, it is essential to assess the reliabilities and validities of the study constructs. The reliability of the constructs can be measured in terms of indicator's reliabilities and internal consistency (Chin, 2010). Additionally, the validity is tested through convergent validity and discriminant validity of the constructs. This section deals with the study measurement model containing the internal consistency, indicator reliability, discriminant validity and convergent validity (Gotz, Liehr-Gobbers, \& Krafft, 2010; Hair, Ringle, \& Sarstedt, 2011). The results of outer loadings (confirmatory factor loadings) and quality criteria of measurement models have been verified through Smart PLS 3.0.

The results have revealed that the entire study items indicators are reliable (Hair et al., 2013). Secondly, internal consistency is required to be verified for the validation of measurement model (Hair et al., 2013).

\section{Internal Consistency}

The reliability of indicators is measured through the internal consistency by applying Cronbach's alpha and Composite Reliability (CR). According to Chin (2010) the Cronbach answer the question that indicators are closely related to each other and it use weights for indicators. The Table 1 authenticates the internal consistency for the study constructs.

\section{Convergent Validity}

This is third requirement for the authentication of study measurement models. Convergent validity to identifies the indicator correlation with other indicators under the given theoretical framework of a study (Chin, 2010). Resultantly, Average Variance Extracted (AVE) confirms the convergent validity of the constructs. The values of AVE for the all constructs is higher than 0.50 as given in table 2 , while six items were to removed due to lowest factor of loading in ascending order, for instance PP1, PP2, PMG-5, CC4, CA3 and CA5 to attain the AVE of project success factors. 


\begin{tabular}{|c|c|c|c|c|c|}
\hline $\begin{array}{l}\text { Items/ } \\
\text { Construct }\end{array}$ & PS & РТСОН & PTCOL & РTCOM & PTT \\
\hline CA1 & 0.703 & & & & \\
\hline $\mathrm{CA} 2$ & 0.793 & & & & \\
\hline $\mathrm{CA} 4$ & 0.748 & & & & \\
\hline $\mathrm{CC} 1$ & 0.638 & & & & \\
\hline $\mathrm{CC} 2$ & 0.716 & & & & \\
\hline CC3 & 0.652 & & & & \\
\hline CC5 & 0.712 & & & & \\
\hline PMG1 & 0.662 & & & & \\
\hline PMG2 & 0.64 & & & & \\
\hline PMG3 & 0.704 & & & & \\
\hline PMG4 & 0.666 & & & & \\
\hline PP3 & 0.682 & & & & \\
\hline PP4 & 0.721 & & & & \\
\hline PP5 & 0.711 & & & & \\
\hline PP6 & 0.727 & & & & \\
\hline PP7 & 0.778 & & & & \\
\hline PP8 & 0.753 & & & & \\
\hline PTCOH1 & & 0.864 & & & \\
\hline РTCOH2 & & 0.881 & & & \\
\hline РTCOH3 & & 0.872 & & & \\
\hline PTCOL1 & & & 0.775 & & \\
\hline PTCOL2 & & & 0.824 & & \\
\hline PTCOL3 & & & 0.844 & & \\
\hline PTCOL4 & & & 0.867 & & \\
\hline PTCQM1 & & & & 0.763 & \\
\hline PTCQM2 & & & & 0.788 & \\
\hline PTCQM3 & & & & 0.833 & \\
\hline PTCQM4 & & & & 0.761 & \\
\hline PTT1 & & & & & 0.799 \\
\hline PTT2 & & & & & 0.769 \\
\hline PTT3 & & & & & 0.729 \\
\hline PTT4 & & & & & 0.82 \\
\hline PTT5 & & & & & 0.758 \\
\hline PTT6 & & & & & 0.659 \\
\hline
\end{tabular}

\section{Discriminant Validity}

Finally, the measurement model is confirmed through the discriminant validity test. The difference among the relative constructs is described by this validity test. Hair et al. (2011) explained that discriminant validity to be measured by applying Fornell-Lacker criterion. More specifically, according to Fornell and Larcker (1981) criterion if the variance of its measures higher than the variance shared by other constructs in value, the resulted conclusion is attainment of discriminant validity. 
Table 2

Measurement Model Quality Criteria

\begin{tabular}{lcccc}
\hline & Cronbach's $\alpha$ & CR & AVE & Commonality \\
& & & & \\
\hline Independent Variables & $>0.70$ & $>0.70$ & $>0.50$ & $>0.50$ \\
\hline Project Team Communication & 0.795 & 0.867 & 0.619 & 0.619 \\
Project Team Cohesiveness & 0.843 & 0.905 & 0.761 & 0.761 \\
Project Team Collaboration & 0.847 & 0.897 & 0.686 & 0.686 \\
Project Team Technical Skills & 0.852 & 0.889 & 0.574 & 0.574 \\
\hline Dependent Variable & & & & \\
\hline Project Success Factors & 0.937 & 0.944 & 0.501 & 0.501 \\
\hline
\end{tabular}

Table 3

Fornell-Larcker Criterium

\begin{tabular}{lccccc}
\hline & PTCoh & PTCol & PTCom & PTTS & PS \\
\hline PTCoh & $\mathbf{0 . 8 7 2}$ & & & & \\
PTCol & 0.655 & $\mathbf{0 . 8 2 8}$ & & & \\
PTCom & 0.568 & 0.622 & $\mathbf{0 . 7 8 7}$ & & \\
PTTS & 0.569 & 0.556 & 0.42 & $\mathbf{0 . 7 5 8}$ & \\
PS & 0.745 & 0.748 & 0.717 & 0.618 & $\mathbf{0 . 7 0 8}$ \\
\hline
\end{tabular}

\section{Assessment of the Structural Models}

The structural models help the researchers to systematically evaluate whether the study hypotheses when converted into structural paths are supported by the findings or not (Urbach \& Ahlemann, 2010). After successful validation of measurement model, the structural model can only be analyzed (Chin, 2010). Using PLS-SEM, the structural models are used to evaluate coefficient of determination $\left(r^{2}\right)$, and path coefficients of the relationships $(\beta \mathrm{i})$. Further, it is required to analyzed the structural model by using different test like Collinearity diagnostic, predictive relevance and statistical significance in case of PLS-SEM (Hair et al., 2011). It is verified that there is no multicollinearity exists in structural model because VIF values are less than defined criteria by Hair et al. (2013) for all values. Table 4.3 exhibits Collinearity statistics for the entire variables in the structural model.

Table 4

Multicollinearity Assessment

\begin{tabular}{lc}
\hline Constructs in Reflective Model & VIF \\
\hline Project Teams Cohesiveness & 2.2 \\
Project Teams Collaboration & 2.94 \\
Project Teams Communication & 2.28 \\
Project Teams Technical Skills & 1.71 \\
\hline
\end{tabular}

The table number 4 illustrates the findings of structural path model for the four main hypotheses H1, H2, H3, and H4. The key theme of the model is to study the direct effect of four different dimensions of project team work on Higher Education Commission's projects success factors. The positive and significant relationship is confirmed at even $1 \%$ level of significance. Further, to elucidate the results it can be seen that project team's communication (a dimension) has strongest effect in project, while another dimension; 
Table 5

Relationship between Project Teamwork and Project Success

\begin{tabular}{|c|c|c|c|c|}
\hline Hypothetical Relationships & Path Coefficients & Absolute t-statistic value & Value of $R^{2}$ & Value of $Q^{2}$ \\
\hline H3a: PTComm $\rightarrow$ PS & $0.31^{* * *}$ & 4.23 & & \\
\hline H3b: PTCoh $\rightarrow$ PS & $0.30^{* * *}$ & 3.16 & & \\
\hline H3c: PTColl $\rightarrow$ PS & $0.27^{* * *}$ & 2.86 & & \\
\hline H3d: PTTS $\rightarrow$ PS & $0.16^{* * *}$ & 2.85 & & \\
\hline Project Success Factors & & & 0.74 & 0.696 \\
\hline
\end{tabular}

project team's technical skills reflected the least effect, although path coefficient is significant at $\mathrm{p}<0.01$. Moreover, structural model validity in total with Q-Squared value 0.697 that is greater than zero provide the basic support to the model that project teamwork with different dimensions adequately predicts project success factors. Further, it is concluded from the value of $r^{2}=0.74$ that project teamwork dimensions elucidates up to many percent's variations in project success factors. Finally, this research study and proposed hypotheses are supported by statistical techniques and results.

\section{Conclusion}

The study was conducted in a developing country and found project teamwork as effective tool toward project success, as reported in prior studies of developed countries. Moreover, the project team members working with the same frequency can create a synergetic effect with respect to project success factors. Further, the project team members should realize the importance of their contribution toward project success. The project team members must possess and develop different which is equally important for project success. The study stands distinct to discuss the contribution of project teamwork in project success in a developing country.

Project teamwork dimensions were empirically investigated as independent variables for project success factors in higher education projects of Pakistan. Corresponding with research questions, the researchers interestingly found positive and significant relationship with project success. Furthermore, the impact of project teamwork was examined with individual dimensions on project success factors. The results showed that project teamwork influence the project success in Pakistan. While investigating the individual dimensions of project teamwork, it is found that project teams' communication skill adds preeminently in project success. The project managers, leaders and organization should mainly acknowledge the value and importance of project.

The result of this study is also supported by various renowned studies, for instance (Dong et al., 2004; J. K. Pinto \& Mantel, 1990; Yang et al., 2013; Afzalur Rahim et al., 2001). Thus, the researcher interprets the findings as beneficial toward enhancement of project success rates in Pakistan. This is because there was also a possibility of negative significance of project teamwork on project success particularly in the prevailing culture of Pakistan, but the findings remain unsurprisingly positive and significant. 


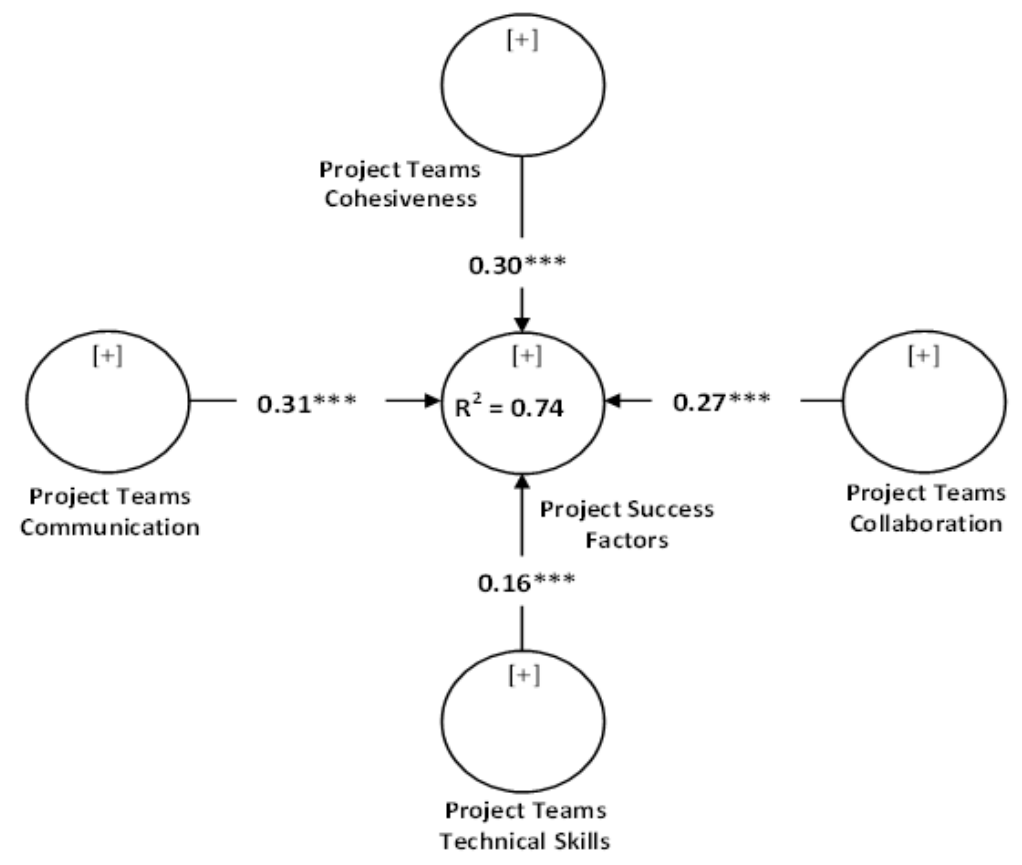

Figure 4.1: Hypothetical Relationship of the Conceptual Model

Moreover, the project teamwork can be further analyzed as a dependent and independent variable in future studies by considering the variable as a single as well as with individual related dimensions duly supported by the literature.

The study unhides several managerial implications to the higher educational institutions and their policy makers. First, the study suggests that these organizations must realize the existence and importance of project teamwork along with project leadership, as it may not only play an important role for enhancing the project success rates but also may contribute to the organizational success. On the other side, the study supports the view that organizations must make their project team members realize the importance of successful projects. Lastly, it is responsibility of the policy-makers and top management to appoint the competent, reasonable and right person for project success to avoid failures at right time. 


\section{References}

Afzalur Rahim, M., Antonioni, D., \& Psenicka, C. (2001). A structural equations model of leader power, subordinates'styles of handling conflict, and job performance. International Journal of Conflict Management, 12(3), 191-211.

Alderman, N., \& Ivory, C. (2011). Translation and convergence in projects: An organizational perspective on project success. Project Management Journal, 42(5), 17-30.

Atkinson, R. (1999). Project management: cost, time and quality, two best guesses and a phenomenon, its time to accept other success criteria. International Journal of Project, anagement, 17(6), 337-342.

Atuahene-Gima, K. (2003). The effects of centrifugal and centripetal forces on product development speed and quality: How does problem solving matter? Academy of Management Journal, 46(3), 359-373.

Baker, B. N., Murphy, D. C., \& Fisher, D. (2008). Factors affecting project success. Project Management Handbook, Second Edition, 35(6), 902-919.

Campion, M. A., Medsker, G. J., \& Higgs, A. C. (1993). Relations between work group characteristics and effectiveness: Implications for designing effective work groups. Personnel Psychology, 46(4), 823-847.

Chin, W. W. (2010). How to write up and report pls analyses. Berlin: Springer.

Clark, K. B., \& Fujimoto, T. (1991). Product development performance: Strategy, organization, and management in the world auto industry. Boston: Harvard Business School Press.

Dionne, S. D., Yammarino, F. J., Atwater, L. E., \& Spangler, W. D. (2004). Transformational leadership and team performance. Journal of Organizational Change Management, 17(2), 177-193.

Dong, C., Chuah, K., \& Zhai, L. (2004). A study of critical success factors of information system projects in china. In Proceedings of th PMI Research Conference, London.

Fornell, C., \& Larcker, D. F. (1981). Evaluating structural equation models with unobservable variables and measurement error. Journal of Marketing Research, 18(1), $39-50$.

Ghori, U. (2009). Impact of faculty development program launched by higher education commission for university teachers. Interdisciplinary Journal of Contemporary Research in Business, 3(3), 1184-1195.

Giritli, H., \& Civan, I. (2008). Personality study of construction professionals in the Turkish construction industry. Journal of Construction Engineering and Management, $134(8), 630-634$.

Gladstein, D. L. (1984). Groups in context: A model of task group effectiveness. Administrative Science Quarterly, 29(4), 499-517.

Gotz, O., Liehr-Gobbers, K., \& Krafft, M. (2010). Evaluation of structural equation models using the partial least squares (PLS) approach. In Handbook of partial least squares (pp. 691-711). Berlin: Springer.

Hair, J. F., Ringle, C. M., \& Sarstedt, M. (2011). The use of partial least squares (PLS) to address marketing management topics. Journal of Marketing Theory and Practice, $18(2), 135-138$. 
Hair, J. F., Ringle, C. M., \& Sarstedt, M. (2013). Partial least squares structural equation modeling: Rigorous applications, better results and higher acceptance. Long Range Planning, 46(1-2), 1-12.

Hair, J. F., Sarstedt, M., Pieper, T. M., \& Ringle, C. M. (2012). The use of partial least squares structural equation modeling in strategic management research. a review of past practices and recommendations for future applications. Long Range Planning, $45(5), 320-340$.

Iqbal, Z., Javed. (2011). Comparative views of research scholars and supervisors regarding the role of higher education commission in developing a research culture in universities. Interdisciplinary Journal of Contemporary Research in Business, 2(11), 312-317.

Kotlarsky, J., \& Oshri, I. (2005). Social ties, knowledge sharing and successful collaboration in globally distributed system development projects. European Journal of Information Systems, 14(1), 37-48.

Krejcie, R. V., \& Morgan, D. W. (1970). Determining sample size for research activities. Educational and Psychological Measurement, 30(3), 607-610.

Levine, J. M., \& Moreland, R. L. (1990). Progress in small group research. Annual Review of Psychology, 41(1), 585-634.

Lu, I. R., Kwan, E., Thomas, D. R., \& Cedzynski, M. (2011). Two new methods for estimating structural equation models: An illustration and a comparison with two established methods. International Journal of Research in Marketing, 28(3), 258268.

M. Afzalur Rahim, C. P., David Antonioni. (2001). A structural equations model of leader power, subordinates' styles of handling conflict, and job performance. International Journal of Conflict Management, 12(3), 191-211.

McGrath, J. E. (1964). Social psychology: A brief introduction. New York: Englewood Cliffs.

Meredith, J. R., \& Mantel Jr, S. J. (2011). Project management: a managerial approach. United States of America;John Wiley \& Sons.

Muller, R., \& Jugdev, K. (2012). Critical success factors in projects: Pinto, slevin, and prescott the elucidation of project success. International Journal of Managing Projects in Business, 5(4), 757-775.

Nelson, K. M., \& Cooprider, J. G. (1996). The contribution of shared knowledge to is group performance. MIS Quarterly, 20(4), 409-432.

Ozorovskaja, R., Voordijk, J. T., \& Wilderom, C. P. (2007). Leadership and cultures of Lithuanian and Dutch construction firms. Journal of Construction Engineering and Management, 133(11), 900-911.

Pinto, J. (1996). Power \& politics in project management. Newtown Square, Pa: Project Management Institute. Retrieved from "http://cds.cern.ch/record/1511608"

Pinto, J. K., \& Mantel, S. J. (1990). The causes of project failure. IEEE transactions on engineering management, 37(4), 269-276.

Reinartz, W., Haenlein, M., \& Henseler, J. (2009). An empirical comparison of the efficacy of covariance-based and variance-based sem. International Journal of Research in Marketing, 26(4), 332-344. 
Ringle, C. M., Sarstedt, M., \& Straub, D. (2012). A critical look at the use of pls-sem in mis quarterly. MIS Quarterly, 36(1), 3-14.

Scott-Young, C., \& Samson, D. (2004). Project success and project team human resource management: Evidence from capital projects in the process industries. In Proceedings of the PMI Research Conference, London.

Sekaran, U., \& Bougie, R. (2010). Research methods for business. London: Wiley.

Sheard, A., \& Kakabadse, A. (2002). Key roles of the leadership landscape. Journal of Managerial Psychology, 17(2), 129-144.

Shenhar, A. J., \& Dvir, D. (1996). Toward a typological theory of project management. Research Policy, 25(4), 607-632.

Slevin, D. P., \& Pinto, J. K. (1986). The project implementation profile. Project Management Journal, 17(4), 57-70.

Solomon, F. B., Hu, Manson, J. E., Stampfer, M. J., Colditz, G., Liu, S., G., C., \& Willett, W. C. (2001). Diet, lifestyle, and the risk of type 2 diabetes mellitus in women. New England Journal of Medicine, 345(11), 790-797. doi: 10.1056/NEJMoa010492

Sunindijo, R. Y., Hadikusumo, B. H., \& Ogunlana, S. (2007). Emotional intelligence and leadership styles in construction project management. Journal of Management in Engineering, 23(4), 166-170.

Thamhain, H. J. (2004). Linkages of project environment to performance: Lessons for team leadership. International Journal of Project Management, 22(7), 533-544.

Tjosvold, D. (1988). Cooperative and competitive dynamics within and between organizational units. Human Relations, 41(6), 425-436.

Unger-Aviram, E., Zwikael, O., \& Restubog, S. L. D. (2013). Revisiting goals, feedback, recognition, and performance success: The case of project teams. Group \& Organization Management, 38(5), 570-600.

Urbach, N., \& Ahlemann, F. (2010). Structural equation modeling in information systems research using partial least squares. JITTA: Journal of Information Technology Theory and Application, 11(2), 5-40.

Verburg, R. M., Bosch-Sijtsema, P., \& Vartiainen, M. (2013). Getting it done: Critical success factors for project managers in virtual work settings. International Journal of Project Management, 31(1), 68-79.

Wang, E., Chou, H.-W., \& Jiang, J. (2005). The impacts of charismatic leadership style on team cohesiveness and overall performance during ERP implementation. International Journal of Project Management, 23(3), 173-180.

Yang, L.-R., Huang, C.-F., \& Wu, K.-S. (2011). The association among project manager's leadership style, teamwork and project success. International Journal of Project Management, 29(3), 258-267.

Yang, L.-R., Wu, K.-S., \& Huang, C.-F. (2013). Validation of a model measuring the effect of a project manager's leadership style on project performance. KSCE Journal of Civil Engineering, 17(2), 271-280.

Zwikael, O., \& Unger-Aviram, E. (2010). Hrm in project groups: The effect of project duration on team development effectiveness. International Journal of Project Management, 28(5), 413-421. 